\title{
İslamî Devrim Nedir?: 1979 İran Örneği
}

\author{
MEHMET TALHA PAŞAOĞLU* \\ pasaoglu@gmail.com \\ ORCID ID: 0000-0003-3427-0730
}

Öz: İran Devrimi (1979) sosyal bilimler literatüründe "İslamî devrim" adıyla anılmaktadır. Bu çalışmada, İslamî devrim kavramı, İran Devrimi örneğiyle ilişkili olarak ele alınmaktadır. İlk olarak devrim nedir sorusu etrafindaki tartışmalara göz atılmışve kavramın hem sosyal bilimler literatüründe hem de İslam kaynaklarında nasıl geçtiğine bakılmıştır. Bu tartışmalardan hareketle İslamî devrimin tarifi yapıldıktan sonra, İan Devrimi hem bir süreklilik hem de kopuş olarak anlamlandırılmıştır. İslamî Devrim, Allahin el-Adl isminin bir yansıması olarak adaletin er ya da geç tecelli edeceği inancına referans verirken, aynı zamanda modernite tecrübesinin etkisiyle halkın kendi hayatının öznesi olduğu düşüncesiyle iç içe yorumlanmıştır. 20. yüzyılın bu açıdan bakıldığında en özgün ani ve köklü değişim örneği olan İran Devrimi, silinmez bir iz bırakmıştır.

Anahtar kelimeler: Devrim, İran, İslamî devrim, İslam.

\section{Giriş}

Devrim nedir sorusunun cevabı sosyal bilimler literatüründe çok defa verilmiş, ancak devrim kavramı hakkındaki tartışmalar nihayete ermemiştir. Devrimin tanımı ve tarifi, sosyal bilimcilerin baktığı açıya göre değişebilmektedir. Devrim derken neyi kast ettiğimiz ilk başta çok açık ve ortak gibi görülebilir. Ancak devrim kavramına ilişkin tartışmalar aynı zamanda Fransız Devrimi’nden (1789) bugüne birçok siyasi tarih tartışmasını da kendiliğinden içerdiği için muhteliftir ve bu kavramın izahını zorlaştırmaktadır. Bu çalışmada, devrim kavramı, günümüz sosyal bilimler literatüründeki tartışmalar ışığında yorumlandıktan sonra İslam'daki inkılap düşüncesi irdelenecek ve İran örneği üzerinden İslamî devrimin bir izahı yapılmaya çalışılacaktır.

Çalışmanın yöntemi, vaka analizidir. Vaka analizinin yöntem olarak belirlenmesinin nedeni İran Devrimi'nin İngilizcedeki "Islamic Revolution" ifadesinin bir çevirisi olarak İslamî Devrim kavramını inceleyebileceğimiz en yetkin ve belki de yegane örnek olmasıdır. Günümüzde "İslamî Devrim” ifadesi neredeyse hiç tartışılmamak-

\footnotetext{
* Arş. Gör., Ondokuz Mayıs Üniversitesi, İİBF, Siyaset Bilimi ve Kamu Yönetimi Bölümü.
} 
tadır. Tamamen kendine özgü bir olay olan 1979 İran Devrimi’nden sonra dünya böyle bir olaya hiç şahit olmadı. Muhtelif coğrafyalarda İslam adına savaştı̆̆ı (cihad) iddiasında olan çok sayıda siyasi grup bulunuyor fakat İran Devrimi’nin 1977-1979 yılları arasında halkın nerdeyse tamamında kazandığı meşruiyeti, hiçbir Müslüman topluluk ve hareket kendi özelinde sağlayamamıştır. Şu halde, "Islamic Revolution" ifadesini İran örneğini anmadan incelemek akademik literatür dahilinde mümkün görünmemektedir. Hatta bu ifade bazen 1979 İran örneği ile o denli özdeşleşir ki onu İranlıların tecrübesinden bağımsız olarak düşünmemiz zorlaşır. ${ }^{1}$

İran örneğinin önemi, aynı zamanda devrimler tarihinde de kendine özgü bir konum işgal etmesi ve "devrim" kavramıyla ilgili anlaşılma biçimlerini yerinden etmiş olması ile ilgilidir. Fransız Devrimi, iki yüzyıla yakın bir süre boyunca takip eden tüm diğer devrimci deneyimlerin ana referans noktasıydı. 20. yüzyılın devrimci/ milliyetçi bağımsızlık mücadelelerinin hemen hemen hepsi 1789'dan esinlenmeye veya etkilenmeye devam etmişlerdir. Sadece 1979'daki İran Devrimi, 20. yüzyılda Fransız Devrimi'nin hegemonyasını kıran bir deneyim oldu. Bundan böyle devrimci hareketler, Fransız Devrimi'ni merkeze almakla sınırlı kalmayacaktı. Devrimler artık sadece Fransız Devrimi’nden kaynaklanan Aydınlanma fikirleriyle açıklanmamaktadır ve yine, devrimci hareketlerin artık zorunlu olarak ulusal talepler veya milliyetçi nedenlerle oluşması gerekmemektedir.

Bugün "devrim” tanımlarının ortak bir noktası varsa hepsinin ani ve köklü bir değişimden söz etmeleridir. Choncheh Tazmini, onu hem devletin kurumlarında ve meşruiyet kaynaklarında, hem de toplumsal yapılarda gerçekleşen ani ve köklü değişim olarak tanımlar. ${ }^{2}$ Bu tanım, devrim kavramı tartışmalarına dair önemli bir ipucu sunmaktadır: 1. Devletin iktidar mekanizmalarının tepesinde ve kurumsal yapılarda bir alaşağı olma; 2. yalnızca devletin kurumlarında ve kadrolarında değil toplumun yaşayışında bir değişim; 3. bu değişimin doğal seyrinden çok daha hızlı olması; 4 . "doğal seyir" derken kast ettiğimiz sistem içi meşruiyet kanallarını aşan yeni bir meşruiyet kaynağı bulması veya doğurması söz konusudur. Theda Skocpol ise devrimi, toplum yapılarının aşağıdan sınıf merkezli bir isyan sonucu ani dönüşümüne bağlamakla birlikte, onun halklar tarafından yapılan bir şey değil (bir yerden) gelen bir olgu olduğuna inanır. ${ }^{3}$ Burada da yeni bir tartı̧̧ma söz konusudur: Devlet ve toplum yapılarını kökten değiştiren bu olgu meşruiyetini nereden, kimden alır ve buradan hareketle devrimin bir öznesi var mıdır? Devrim eğer yapılan bir şeyse onu kim yapar, eğer gelen bir şeyse kimden gelir, şayet bir yerden gelen değil de ortaya çıkan bir olguysa onu ortaya çıkaran nedir/kimdir?

Zhand Shakibi, Fransa, Rusya ve İran devrimlerinin karşılaştırmalı analizini yaptı̆̆ 1 çalışmada devrilen liderlerin karakterine vurgu yapar ve yapısal değişkenlerin bi-

1 Söz konusu ifadenin Türkçeye genellikle "İslam Devrimi” diye çevrilmesi, İslam ve devrim arasındaki ilişkinin doğrudan 1979 İran örneğini imlemesi bakımından kayda değerdir. Şahsen “İslamî Devrim” ifadesinin daha doğru bir çeviri olduğunu düşünüyorum. İslam devrimi tek bir olayı ima ederken, İslamî devrim bir türü ifade etmektedir.

2 Choncheh Tazmini, Revolution and Reform in Russia and Iran, New York: I.B.Tauris, 2012, s.20.

3 Theda Skocpol, "Rentier State and Shia Islam in the Iranian Revolution", Theory and Society, 11/3 (1982), s.265283. 
reylerin tutumlarıyla etkileşimli olarak devrimi getirdiğini savunur. ${ }^{4}$ İran Devrimi ile ilgili literatürün neredeyse tamamı, Ayetullah Humeyni’nin inkılabın lideri olduğunu kabul eder. Gerçekten sürgünden gönderdiği yazılarla Humeyni, muhtelif direniş hareketlerinin ortak sembolü haline gelir. 1970’lerde devrimci gruplar sık sık hükümeti eleştiren bildiriler yayımlar ve taleplerini sıralarlar. Bu taleplerin başında, Humeyni'nin sürgünden geri dönmesine izin verilmesi de yer alır ve sokaklar, "Humeyni’ye özgürlük!” sloganlarıyla yankılanır.

Skocpol, 1979'dan önce devrimlerin “yapılan” değil ülke dışından "gelen” bir müdahale sonucu gerçekleştiğini iddia ederken, İran Devrimi örneğinde devrimin dişardan gelen değil içerden yapılan, failin faaliyetiyle ortaya çıkan gerçekliğini kabul etmiştir. ${ }^{5}$ Ervand Abrahamian ise, İran Devrimi'nin yapısal sebeplerini yazarken, ülke dışından değil içerden bir toplumsal hareket vurgusu yapmaktadır. ${ }^{6}$ Benzer şekilde, Misagh Parsa İran Devrimi'ni collective action (kolektif eylem) kavramıla açıklamakta ve muhtelif grupların ortak bir eylemliliğe katkı yaparak Şah rejimini devirdiğini anlatmaktadır. ${ }^{7}$ Asef Bayat, 1979 öncesi ve sonrası işçi sınıfını mercek altına aldığı kitabında, pazar esnafının, küçük burjuva, proleterleşmiş kitleler ve görece iyi durumdaki işçi sınıfı ile devrimi gerçekleştirdiğini söyler. ${ }^{8}$ İran Devrimi’nin İslamî bir arayışın ve haykırışın neticesi olup olmadığına gelince, Mehrzad Boroujerdi, 1979'un öncesi ve sonrasında öne çıkan İranlı entelektüelleri incelediği çalışmasında "Şiilik devrimin anahtarıydı fakat tek ideolojik bileşeni değildi” der. ${ }^{9}$ Boroujerdi’nin bu şerhini kabul etmekle birlikte, Asef Bayat'ın yorumunu da dikkate alarak, diğer ideolojik bileşenlerin değil, "devrimin anahtarı" ve "gayretin kaynağı" olan kültürün (İran özelinde Şiiliğin) belirleyiciliğini es geçmemek gerekir; Isaac Kramnick’in dediği gibi, devrim, bir açıdan kültürel bir fenomen olup insanların dünyayla ilişkilenme biçimlerini değiştirir ve onların dünya görüşünde köklü bir kabuk değişimi demektir. ${ }^{10}$ Mamafih bu dönüşüm, ilginç bir şekilde, zaten var olan toplumsal ifade biçimlerinden neşet eder.

Burada, her hâlükârda bir olgudan, yani sonradan adı konan ve devrim adını almış bir olaydan söz edilmektedir. Böylece bu olayın bir tarihsel süreç içerdiği ima edilmektedir. Yani devrimlerin bir sürecin sonunda olgunlaştığını dolayısıyla bir çeşit süreklilik taşıdığını söylemiş oluyoruz. Devrimler, eğer bu anlamda birer süreklilik ise onları "ani ve köklü değişim” olarak açıklamak yeterli midir? Köklü değişim bir önceki toplumsal ve siyasi yapının, yerini yeni bir yönetime ve toplumsallığa bırakışını ifade eder. Değişimin kurulu düzen içindeki meşru kanalları aşması ve doğal seyrinden çıkması ise eskisinden bir kopuş ve ani değişim anlamına gelir. Öyleyse

4 Zhand Shakibi, Revolution and the Collapse of the Monarchy: Human Agency and the Making of Revolution in France, Russia and Iran, London: I.B.Tauris, 2007.

5 Skocpol, "Rentier State and Shia Islam in the Iranian Revolution”, s.265-283.

6 Ervand Abrahamian, Iran Between Two Revolutions, Princeton: Princeton University Press, 1982.

7 Misagh Parsa, Social Origins of the Iranian Revolution, Rutgers: Rutgers University Press, 1989.

8 Asef Bayat, Workers and Revolution in Iran: A Third World of Experience of Workers' Control, London: Zed Books Ltd., 1987.

9 Mehrzad Boroujerdi, İran Entelektüelleri ve Batı, çev., Fethi Gedikli, İstanbul: Yöneliş Yayınları, 2011, s.17. 10 Isaac Kramnick, "Reflections on Revolution: Definition and Explanation in Recent Scholarship", History and Theory, 11 (1972), s.26-63. 
devrimleri, yalnızca ani ve köklü bir değişim değil, aynı zamanda hem bir süreklilik, hem de bir kopuş olarak tarif etmek gerekir.

\section{Süreklilik ve Kopuş}

Alain Rey'e göre, devrim kavramı süreklilik ve kopuş, geçmiş ve gelecek, yıkma ve yeniden kurma gibi zıt anlamları zaten birlikte barındırır. ${ }^{11}$ Onu tartışmayı bu kadar zor kılan da budur. Kavramın "ideolojik yükünün”12 ağırlığını da düşününce, ortak bir tanım bulmanın mümkün olmadığı ortaya çıkar. Devrimci sahiplenmeler, tarihsel bir birikime yaslanmak istiyorsa geçmiş ve süreklilik vurguları ön plana çıkacaktır. Eski ve bozuk düzenin ilgası kutsanıyorsa, kopuşun ve yeni bir gelecek kurmanın şarkıları söylenir. Öte yandan kimileri için aynı devrim, eski ve özlenen günlerden kopuşu ve yıkımı simgeleyebilir. Yıkım ve yeniden yapılanma her devrimde vardır ama yıkıma yüklenen olumlu ve olumsuz anlamlar tartışmanın saflarını belirler.

Aynı şekilde ani ve köklü değişimin şiddeti içerip içermediği de böyle tartışmalarda anahtardır; örneğin bir devrimi olumsuzlayan yazarlar onun teorikte ve/veya pratikte şiddet olgusunu içerdiğini vurgularlar... ${ }^{13}$ Arthur Hatto, devrimi "basitçe, bir hükümeti değiştirmenin tanınmış, yasa-üstü bir yöntemi”'14 diye tanımlarken eski rejimin yasa dışı olmakla birlikte halk nezdinde kabul görmüş bir yolla devrilmesinden söz eder ve böylece bize devrimde yeni bir meşruiyet, dolayısıyla yeni bir toplumsallık doğduğunu hatırlatır. Paul Schrecker, siyasal değişimi devrim diye adlandırmamız hukukun etkilenmesi ve değişimin yıktığı hukuk nezdinde illegal olmasıyla mümkündür, der; yani devrim, anayasanın ya da bizzat yasallığın illegal değişimi demektir. $^{15}$

Devrim kavramının şiddet içerikli olup olmadığını buradan hareketle yorumlayabiliriz. Georges Sorel, devletin insanlara uyguladığı fiziksel kuvveti "güç" ile, işçi sınıfının ortaya çıkardığı isyanı ise "şiddet” ile açıklar: "Böylece gücün, azınlığın yönettiği belli bir sosyal düzene sahip örgütlenmeyi benimsetmek amacı taşıdığını, şiddetin ise bu düzeni yok etmeye yeltendiğini söyleyebiliriz." ${ }^{16}$ Devrim, var olan düzeni (statüko) değiştirmenin "illegal metodu” ise şiddet kavramından ayrı düşünülemez. Bununla birlikte, devrim tartışmalarında bu kavrama "zor kullanımı” yerine "ihlâl olarak şiddet”"17 diye bakmak yerinde olur. Çünkü kurulu düzeni, bizatihi bozan, sekteye uğratan, ihlal eden durumlar şiddeti ifade eder ki böylece, hali hazırdaki toplumsal işleyiş biçimlerini yıkan (bir kopuş olan) devrimi görmek mümkün olur.

Perez Zagorin’e göre, bastırılan grupların hükümeti, rejimi veya toplumu şiddet

11 Alain Rey, "Révolution", Histoire d’un mot, Paris: Gallimard, 1989, s.18.

12 Felsefe Ansiklopedisi, ed., Ahmet Cevizci, 4. cilt, Ankara: Babil Yayınları, 2006, "Devrim” maddesi.

13 "Devrimin "nasıl” gerçekleştiğine cevap arayanlar tanımda şiddete öncelik vermekte, "neyi” değiștirdiğine cevap arayanlar ise devrim tanımına şiddeti katmamaktadırlar." Felsefe Ansiklopedisi, s.282.

14 Arthur Hatto, "Revolution: An Inquiry into the Usefulness of an Historical Term”, Revolution: Critical Concepts in Political Science, ed., Rosemary H. T. O’Kane, London: Routledge, 2000, s.18.

15 Paul Schrecker, "Revolution as a Problem in the History of Philosophy", Revolution, ed., Card J.Friedrich, Atherton: Atherton Press, 2009. s.34-53.

16 Georges Sorel, Réflexions sur la Violence, Paris: Libraire des Sciences Politiques et Sociales, 1910, s.240.

17 Aykut Çelebi, “Bir Parıltı... Sonra Gece”, Şiddetin Eleştirisi Üzerine, İstanbul: Metis Yayınları, 2010, s.12. 
yoluyla değiştirme girişimleri devrimi ifade eder. ${ }^{18}$ Karl Griewank için devrim, devletin ve hukukun kurumlarını değiştiren, doğası gereği yıkıcı ve şedit bir süreçtir. ${ }^{19}$ Ne var ki, sürecin ideolojik programlar dahilinde bir yeniden yapılanmayı içerdiği unutulmamalıdır. Devrimleri incelerken bu yapıcı ve yıkıcı, pozitif ve negatif unsurların birlikte başat ve etkin olduğu süreçleri devrimci durum kavramıyla açıklayabiliriz. Eric Hobsbawm’a göre devrimci durum, çeşitli ve kısa dönemli krizlerin uzun dönemli iç çatışmalarla devrimci sonucu doğurması olarak tanımlanabilir. ${ }^{20}$ Yani devrimci durumlar, farklı çatışma alanlarıyla muhtelif ihtimale açık, yaratıcı süreçlerdir. Yeni bir toplumsallık ve köklü değişim oradan çıkmaktadır. Ne var ki, devrimci durum esnasında yeşeren her ihtimal sonradan yaşama şansı bulamaz. Charles Tilly, devrimleri devrimci örgütlerin siyasal rekabetinin sonucuna bağlarken, onların gelecek programlarının başarısının, yapısal ve toplumsal değişimle sınırlı olduğunu vurgular. ${ }^{21}$ Ani ve köklü değişim sonrasında kurulan yeni yönetim ve yeni toplumsal yapı, devrimci durum sırasında belirmiş muhtelif ihtimali dışlayacaktır. Çoğu zaman yeni yönetim, yeni güç gösterme biçimleriyle yeni rejimi güçlendirmeye çalışacaktır. Yani toplumsal değişimin de pozitif olduğu kadar negatif, özgürleştirici olduğu kadar baskıcı sonuçları olacaktır. Devrim kavramının “ideolojik yükü” ensemizdeyken bir tercih yapmak zorundayı: Devrimleri radikal iyimserliğe de, muhafazakâr yergi alışkanlığına da kapılmadan nasıl okuyacağız? Bu soru, devrimlerin kendine özgü tarihsel şartları kadar devrim kavramının tarihselliği ile birlikte tartışıldığında daha anlamlı olacaktır.

\section{İslamî Devrim Kavramı}

Devrim kavramının bugünkü anlamlarını alması, 1789 Fransız Devrimi’nden sonra olmuştur. Nerdeyse tüm devrim literatürü varlığını 1789'a borçludur. Fransız Devrimi, “ani ve köklü değişimi” tanımlayan ilk halk ayaklanmasıdır ve önündeki iki asrın referans noktası olmuştur. Burada, Fransız Devrimi’nin tarihsel, sosyolojik ve düşünsel etkileri bir yana, devrim kelimesinin bugünkü anlamlarına katkısını hatırlamak gerekir. 14 Temmuz 1789 günü Bastille’in düştüğü haberini alan XVI. Louis'nin “c'est une révolte" (bu bir isyan!) deyișine cevaben Duc de la Rouchfoucauld-Liancourt'un "non, sire, c'est une révolution" (hayır, efendim, bu bir devrim!) dediği söylenir. Hannah Arendt'in de vurguladığı gibi, bu, devrimin kaçınılmaz, karşı koyulamaz bir olay olarak yeni bir kullanımına tekabül eder. ${ }^{22}$ Liancourt olayların çı̆̆ırından çıktığını söylemektedir aslında. Olayların doğal seyrinden yani çı̆̆ırından çıkması olarak andığımız şey, budur. Karşı konulamaz, geri döndürülemez bir şey haline gelen devrim, isyandan farklı olarak, bu türden bir "kopuşu" ifade eder. Bu kopuş, legal meşruiyet sınırlarını aşarken aynı zamanda kendi meşruiyetini bulmakta veya doğurmaktadır.

Devrim kavramının tarihselliğinde yer alan bu döngüsellik, karşı konulamazlık ve

18 Perez Zagorin, "Prolegomena to the Comparative History of Revolution in Early Modern Europe", Comparative Studies in Society and History, XVIII (1976), s.151-174.

19 Karl Griewank, Der neuzetliche Revolutionsbegriff, Suhrkamp: Frankfurt-am-Main, 1973, s.85-86.

20 Eric Hobsbawm, "Revolution", Revolutions in History, ed., Roy Porter and Mikulas Teich, Cambridge:

Cambridge University Press, 1986, s.94-95.

21 Charles Tilly, “Does Modernization Breed Revolution?”, Comparative Politics, 5 (1973), s.425-447.

22 Hannah Arendt, On Revolution, New York: Viking Press, 1963, s.40. 
kopuş aslında İslam kaynaklarında da izleri bulunabilecek olgulardır. Devrim sözcüğü, Kur’an-1 Kerim'de de geçer. "Révolution” kelimesinin Arapçadaki en yakın karşılığı olan inkılap’a Şuara suresinin son ayetlerinde rastlarız. Fransızca meallerde "le revirement" (yön değiştirme) diye geçen, İngilizce tefsirlerde "vicissitude" (değişim), "turn back" (geri dönüş) gibi ifadelerle çevrilen terim, hem değişim, hem de gündönümü anlamına gelmektedir. 20.yüzyılın ünlü Kur’an yorumcusu Muhammed Esed'in İngilizce çevirisi ise oldukça anlamlıdır:

[Most of them are of this kind] save those who have attained to faith and do righteous deeds, and remember God unceasingly, and defend themselves [only] after having been wronged, and [trust in God's promise that] those who are bent on wrong doing will in time come to know how evil a turn their destinies are bound to take! ${ }^{23}$ (Ash-Shuara 227, vurgular bana ait).

"Onların talihini döndürecek” şey, Türkçe çevirilerde yine devrim/inkılap kavramıyla anilir:

Ama inanan, dürüst ve erdemli davranışlar ortaya koyan, Allah’ı sıkça anan, [sadece] haksızlığa uğratıldıktan sonra kendilerini savunan ve haksızlık yapanların, hangi devrimle devrileceklerini er geç görecekleri [konusunda Allah’ın vaadine güvenen şairler] bu hükmün dışındadır! ${ }^{24}$ (Şuara 227).

Ancak iman edip iyi ameller işleyenler, Allah’ı çokça zikredenler ve kendilerine haksızlık edildikten sonra öçlerini alanlar müstesna. O haksızlık edenler hangi inkılaba münkalib olacaklarını (hangi akıbete yuvarlanacaklarını) yarın bilecekler. ${ }^{25}$ (Şuara 227).

Devrim'in Allah’ın bir vaadi olarak karşı koyulamazlığı ne anlama gelir? Şu ana dek ondan kaçınılmaz, geri döndürülemez bir süreç olarak bahsettik ama dinî referanslarına işaret etmedik. Devrim fikri, Müslümanlar için zalimlerin elbet bir gün - bu dünyada ya da öte dünyada - yenilecekleri anlamını taşımaktadır. Kur’an-1 Kerime göre, o gün hak yerini bulacak ve adalet sağlanacaktır. Bu vaatin kendisi ister dünyevi, ister uhrevi bir mutlu sonu işaret etsin, etkileri tamamen bu dünyaya aittir. Müslümanların tecrübeleri, Kur’an-1 Kerim'i ve bu dünyayı anlamlandırma biçimleri de aynı şekilde bu dünyaya içkindir. Dinin öte dünyayı olduğu kadar bu dünyayı da ilgilendirmesi, onun her durum ve zamanda politik olduğunu hatırlatır. Bununla birlikte, inancın politik sonuçlarını afaki değil tarihsel olgular etrafında tartışmak gerekir ki bu noktada İran Devrimi İslamî Devrim olgusunun en yetkin örneğini verdiği için sırf bu yönüyle dahi incelenmeye muhtaçtır.

23 “The Message of the Qur'an”, haz., Muhammad Asad, son güncelleme 25 Mart, 2018, http://www.kuran.gen. tr/?x=s_main\&y=s_middle\&kid=33\&sid=26.

24 “Kur'an-ı Kerim Türkçe Meali”, haz., Elmalılı Hamdi Yazır, son güncelleme 25 Mart, 2018, http://www.kuran. gen.tr/?x=s_main\&y=s_middle\&kid=31\&sid=26.

25 "Kur'an Mesajı Meal ve Tefsir", haz., Ahmet Ertürk ve Cahit Koytak, son güncelleme 25 Mart, 2018, http:// www.kuran.gen.tr/?x=s_main\&kid=31\&sid=1\&y=s_middle. 


\section{İran Devrimi Örneği}

İslamî Devrim kavramı İran Devrimi ile ilgili çalışmalarda çoğunlukla İslamcılık ideolojisi ile birlikte anılır. İslamcilık, genel olarak, "ne tür bir İslam yorumuna sahip olduğu önemli olmaksızın siyasal pratiğinin merkezine İslam’ı koyan her türlü Müslüman oluşumu"26 ifade eder. Aslında İran Devrimi’nin aktörleri içinde İslamcılar da vardır, İslamcı olmayıp İslamî söylemleri belli oranlarda benimseyenler de. Devrimi bir gerçeklik haline getiren toplumsal muhalefet içinde çok çeşitli siyasal gruplar olup, bunlardan bazıları İslamî bir yönetim idealine bir ölçüde iştirak etmektedir fakat kendini "İslamcı" diye tanımlamıyor olabilir. Bununla birlikte, İslamcılık düşüncesi modern-tarihsel karakteri içinde ele alındığında, İran Devrimi’ni "İslamcilığın zaferi” olarak tarif etmek, kolay ve acele yapılmış bir tespit olur. İslamcılık ile ilgili hali hazırdaki çalışmaların yetersizliği bir yana, İran Devrimi için yapılan İslamcı Fundamentalizm yakıştırmaları, oryantalist tarih yazımının bir örneğidir.

Bu bağlamda İranlıların İslam anlayışında egemen olan Şiilik, doğrudan dinî veya ideolojik bir tercihi değil, dolaşımda olan esnek fakat dominant bir kültürel dili ifade eder. Onun esnekliği dogmalar ve doktrinler etrafında değil insanların günlük yaşamlarında örülü olmasından ileri gelmektedir. Şiiliğin dominant olması ise, dolaşımda olduğu coğrafya özelinde hakîm hayat tarzlarını ve düşünme pratiklerini doğurmasını ifade eder. Şiiliği özü itibariyle devrimci bir inanç veya ideoloji olarak görmek yerine, İranlıların tarihsel serencamı içerisinde yorumlamak gerekir. Şiiliğe farklı ideolojilerden ve toplumsal sinıflardan insanları devrimci bir güç haline getiren ortak bir dil olarak bakmak gerekir. Bu çerçevede, Şiiliğin moderniteyle ilişkisi es geçilmemelidir.

İran Devrimi’nin İranlıların modernite tecrübesine içkin bir ayaklanma ve 20 . yüzyıla has, özgün bir olay olduğu unutulmamalıdır. Hamid Dabashi, İran’da siyasal kültürün Şiilikle örülü olduğuna vurgu yaparken Şii olmanın anlamlarının sosyo-ekonomik duruma göre değiştiğini söyler. Örneğin yoksullar ve orta sınıf esnaf için din bütün boyutlarıyla hayatı kuşatır ve Şii ulema onlar için önemli bir otoritedir. Diğer İranlılar içinse o, daha çok "kültürel karakter, duygular evreni, normatif davranış, etik prensipler, ahlaki emirler veya kültürel dağarcık" olarak vücut bulur. ${ }^{27} \mathrm{Bu}$ bağlamda Şiilik derken kastımız, onun sadece dinî değil, daha ziyade bütün bu boyutları içine alan bir toplumsal gramer olmasıdır.

İranlıların İslam’ı anlama ve yaşama pratikleri Şiilikten ayrı düşünülemez; aynı şekilde Şiiliği idrak ediş ve yaşayış biçimleri de sadece İslam ile açıklanamaz. İranlıların kolektif hafızasına ve anlam dünyalarına dair topyekün bir fikir edinmek yerine, birbiriyle tamamlayıcı görünen parçalı tecrübelere bakmak gerekir. 1979'a gelene kadar, İran’n siyasal kültüründe ve dönüşüm serüveninde yaklaşı 100 yıllık bir protesto geleneği olduğunu söylemek mümkündür. Bu protesto geleneği nasıl oluşmuştur, farklı biçimlerde yıllarca süren iktidar karşıtı protestolar ve grevler meşruiyetlerini nereden almaktadır? 1979 İran Devrimi ona tanıklık eden halk kitleleri nezdinde 
ne anlama gelmektedir? İran Devrimi bir "İslamî Devrim” ise onun öznesi kimdir, Müslümanlar mı, İslamcılar mı, yoksa bir başkası mı?

İran'da İslamî Devrim düşünün sokak protestoları ve grevler yoluyla taze tutulduğunu, halkın muhtelif kesimleri tarafından sahiplenildiğini ve bir hakikat söyleminin gün be gün oluşturulduğunu söylemek mümkündür. İşçilerin, esnafın ve öğrencilerin hem ekonomik hem siyasi temelli itirazları ve isyanları, çok parçalı bir direnişin tekil tecrübeleri olmakla birlikte, ortak bir "iyi yönetim” idealine dayanıyordu ve giderek kolektif hale gelen bir muhalefet hareketiydi. Şiiler, 1970'lerde Şah rejimiyle mücadelelerini Hz. Hüseyin-Yezid karşıtlı̆̆ına benzeterek, devrimci bir söylem kurmayı başardılar. Michel Foucault'ya göre Şii ulema devrimci değildi ama İranlı Müslümanlar Şah'a karşı ortak bir irade göstererek dinin toplumun afyonu olmadığını gösteriyorlardı. ${ }^{28}$ Foucault'nun 1978 sonbaharında İran'a yaptığı iki yolculuk onu etkilemişti. Corriere della Serra gazetesine yazdığı yazılarda insanların İslam için ölüme koştuğunu, "siyasal maneviyatın” dünyaya yeni bir şey getirebileceğini söylüyordu. Yazıları Avrupalı birçok aydın tarafından sert eleştirilere maruz kaldı. Özellikle 1979'da, Şah'ın devrilmesinden sonra kurulan yeni yönetimin baskıcı bir kimlik kazanması, feministlerin ve liberallerin hışmına uğramasına neden oldu. Aslında o da bu ani ve köklü değişimin varabileceği noktaları öngöremediğini fakat muhalif hareketlerin modern-liberal hegemonyay ${ }^{29}$ aşan bir mahiyet içerdiğini vurguluyordu.

Ervand Abrahamian’a göre Muhammed Rıza Şah da tıpkı babası gibi iktidarını silahlı kuvvetler, patronaj ağı ve bürokrasi üstüne oturtmuştu. Ayrıca Pehlevi ailesi ülkenin en büyük toprak zengini ve sahip olduğu fabrikalar sayesinde en müreffeh girişimcisi olmuştu. ${ }^{30}$ İki partili İngiliz modeline geçen Şah, 1963’te Yeni İran Partisi'ni kurdurdu ve başkanı Hasan Mansur'u başbakan yaptı. Mansur yabancı şirketlere yeni petrol imtiyazları vermeye kalkınca 1965'te muhalif öğrenciler tarafından öldürüldü. İki ay sonra bu kez Şah, silahlı saldırıya uğradı. 1965-1970 yılları arasında gerilla teşkilatı kurup dağa çıkan Marksist-Leninist gençler bir polis karakoluna saldırarak iki jandarmayı öldürdüler ve yakalanıp idam edildiler; ${ }^{31}$ yine, 50 üyesi bulunan ve Hürriyet Hareketi ve Milli Cephe'den kopmuş gençlerden oluşan Mücahidin-i Halk ise, hükümeti silahla devirmeyi amaçladı ancak 1971'de planladığı gerilla savaşını başlatamadan yakaland132. 1973’te bir SAVAK ajanı ve birkaç Amerikan elçiliği çal1şanı, 1974’te iki yıl önceki bir grevde öldürülen işçilerin patronu, 1975’te bir muhafız birliği komutanı ve iki Amerikalı albay suikasta uğradılar. ${ }^{33}$ Silahlı mücadele küçük devrimci gruplar tarafından başlatılmış fakat henüz halka yayılmamıştı.

28 Janet Afary ve Kevin B. Anderson, Foucault ve İran Devrimi: Toplumsal Cinsiyet ve İslamcılı̆̆ın Ayartmaları, çev., Mehmet Doğan, İstanbul: Boğaziçi Üniversitesi Yayınları, 2015.

29 Hegemonya, Ranajit Guha’nın tarifiyle "mecburen ve indirgenemez bir biçimde zora ve rızaya dayanan somut tarihsel ilişkidir". Ranajit Guha, Dominance without hegemony: History and power in colonial India, Cambridge: Harvard University Press, 1997, s.23.

30 Abrahamian, Iran Between Two Revolutions, s.440.

31 Hamide Muhammed, İran İslam İnkılabı, çev., M. Selman, Ankara : Kevser Yayınları, 1993, s.175.

32 Muhammed, İran İslam İnkılabı, s.174-176.

33 Muhammed, İran İslam İnkılabı, s.284. 
1975 yılında Şah, Rastakhiz Partisi'ni kurdu ve tek parti yönetimine geçti. Humeyni, Necef'ten gönderdiği mesajda halkı bu partiye rağbet etmemeye ve Feyziyye Medresesi’nde toplanmaya çağırdı. Kalabalıklar toplandıktan bir gün sonra medrese polis tarafından işgal edildi, 500 kişi tutukland..$^{34}$ Bütün mebusları Rastakhiz Partisi mensubu olan meclis, Ekim ayında Hicrî takvimi kaldırdı ve 2500 yıl önceki İmparatorluk dönemini milat kabul eden yeni bir takvime geçmeyi kabul etti. ${ }^{48} \mathrm{Bu}$ hamle, Şii muhalefeti gözünde akıl almaz bir cüretti. Daha önce de dinî kitapların basımının yasaklanması, kimi ulemanın faili meçhullere kurban gitmesi ve birçok ayetullahın tutuklanması rejimi güçlendirmemiş, zayıflatmıştır. ${ }^{35}$

Bu arada Ağustos 1971'de kurulan "dinî polis güçleri” köy köy dolaşıp halka "gerçek İslam’ın" Humeyni ve yanlılarının temsil ettiği din olmadığını anlatmaya çalışıyorlardı. Hükümet üç aşamalı bir plan hazırlamıştı: 1. Ulemanın siyasete karışmasının kabul edilmeyeceği anlatılacak; 2. Muhalefet eden ulema, devletin din adamlarına sağladığı haklardan yararlanamayacak; 3. Israr eden din adamları hapse atılıp cezalandırılacak. ${ }^{36} 1975$ 'te Meşhed'de, Kum'da ve Tahran'da ne kadar muhalif kurum ve medrese varsa hepsi kapatıldı. 1976'da Şah’ın İslam öncesi Pers takvimine geçme kararı alması, ulemada büyük tepki uyandırdı. Humeyni’nin eski öğrencilerinin öncülük ettiği muhalif ulemanın önde gelenleri, Şah’a açıkça karşı çıktıkları için tutuklandılar. Hüccetülislam ve Ayetullah gibi yüksek makamlara gelmiş din adamları işkence gördüler ve öldürüldüler.

Ekim 1977'de Humeyni'nin oğlu Mustafa, Irak'in Necef kentinde aniden vefat etti. O da babası ile birlikte sürgündeydi ve İranlılar için onun ölümü, Şah’ın güvenlik politikasını sorumlu tutmak için yeterliydi. Bu sebeple başlayan kitlesel gösteriler Ocak 1978'de Humeyni karşıtı bir gazete yazısının etkisiyle isyana dönüştü. Kum'daki isyan sırasında ölenler, yeni isyanların habercisiydiler. 1978'in ilk ayları Kum, Tebriz, Yezd ve Tahran'da ilahiyat öğrencilerinin ve mollanın örgütlediği gösterilerle geçti.

Şah rejimine muhalif olmakla birlikte, Humeyni'den ve onun etrafında örgütlenen ulemadan farklı konum alan din adamları da vardı. Örneğin, Ayetullah Şeriatmedari’nin görüşleri Humeyni'den farklıydı. O, Şah’ı anayasaya uymaya davet etmiştir ve ancak başka seçenek kalmadığı zaman silahlı mücadeleye geçilebileceğini söylemiştir. Humeyni “insan kanının nehir gibi akacağı” günlere vurgu yaparken o, daha fazla kan dökülmeden seçimlere gidilmesini istemiştir. ${ }^{37}$ Bununla birlikte, muhalefetin bölünmesini istemediği için Humeyni’nin İran halkını temsil ettiğini belirtiyor ve "biz halk içinden halk için bir hükümet istiyoruz" diyordu. ${ }^{38}$ Şeriatmedari yalnız değildi, hem Şah yönetimine karşı olup hem talepleri siyasi tutsakların salıverilmesi, İslamî olmayan yasaların yürürlükten kaldırılması ve Savak’n lağvedilmesi ile sınırlı olan çok sayıda molla vardı. Parsa'ya göre ulemanın çoğu bu çizgideydi; talepleri İslamî yönetimdi ama ulemanın ayrıcalıklı bir konuma çıkacağı bir İslam

34 Ehsan Yar-Shater, Iran Faces the Seventies, New York: Praeger Publishers, 1971, s.203-204.

35 Abrahamian, Iran Between Two Revolutions, s.445-446.

36 Ahavi, İran'da Din ve Siyaset, s.239-240.

37 Ahavi, İran'da Din ve Siyaset, s.297.

38 Ahavi, İran'da Din ve Siyaset, s.296. 
Devleti’nden söz etmiyorlardı. Aralarında Humeyni’nin liderliğini kabul edenler kadar, siyasal vizyonuna uzak olan ve devlet işlerine karışmak istemeyen bir kesim de vardı. Bu kesim, öldürülenlerin cenaze törenlerini politik sloganlardan uzak yapma arzusundaydı. Bunun dışında küçük bir kesim de Şah’ın yanında yer alıyordu. Ancak ölümler arttıkça bunların ne kadarının aynı çizgide kaldığını bilmiyoruz.

Ayetullah Humeyni'nin azmi on beş yıla dayanan mücadelesiyle birlikte onu devrimin sembolik lideri haline getirmiştir. Yaşananların uzağında oluşu onun isminin mitleştirilmesine olanak sağlamıştır. Öte yandan Humeyni 12. İmam (Mehdi) gelene kadar bekleyip zamanı geldiğinde onunla birlikte hareket etmek gerektiğini vaaz edenlere şiddetle karşı çıkmıştır ve beklemenin (intizar) sorumluluğa ve mesafe almaya işaret ettiğini söylemiştir. Humeyni İslamî devrim tabirini ilk kez kullandığ 1 Ağustos 1978'de bu isyan ateşini şehitlik söylemiyle körükleyip ölenlerin devrimi kanlarıyla suladığından bahsetmiştir. Bu kutsama ile Humeyni insanları siyasal maneviyat uğruna ölüme koşmaya çağırmaktadır.

Bütün Müslümanlarca kutsal olan Ramazan ayının sonunda (Eylül 1978) gösteriler artmış ve büyük çaplı grevler başlamıştı. Humeyni yayınladığ hareketlerin daha da büyümesini, askerlerin ve kamu görevlilerinin de isyan etmesini istiyordu. ${ }^{39}$ Aşağıdaki tabloda verilen çatışmalar, baskıcı bir yönetim karşısında muhalif grupların sivil direnişten silahlı mücadeleye nasıl geçtiklerinin veya geçmek zorunda kaldıklarının birer örneğidir:

Tablo 1. Devrim Yolunda

\begin{tabular}{|c|c|c|c|}
\hline Tarih & Olay & Kim / Nerede? & İçerik / Sonuç \\
\hline Ekim 1978 & Yürüyüş & $\begin{array}{l}\text { Tebriz’de } 5000 \text { kişi, Tahran } \\
\text { Üniv'de } 5000 \text { öğrenci ve } \\
\text { Raş’te } 2000 \text { kişi yürüdü. }\end{array}$ & $\begin{array}{l}\text { Ellerinde 50'lerde asılan bir } \\
\text { Komünist Fedayin üyesinin } \\
\text { fotoğrafı vardı. İşçi, köylü ve } \\
\text { yazarlar da destek verdiler. }\end{array}$ \\
\hline 31 Ekim 1978 & Yürüyüş & $\begin{array}{l}25000 \text { Kürt Senendec'de } \\
\text { protestolara katıldı, diğer } \\
\text { illere de yayıldı. }\end{array}$ & $\begin{array}{l}\text { Keşan'da silahlandılar. } \\
\text { Baneh’te köylüler de yürüyüşe } \\
\text { katıldılar. }\end{array}$ \\
\hline 3-4 Kasım 1978 & Çatışma & $\begin{array}{l}\text { Polis Akademisi ateșe } \\
\text { verildi. Kermanşah'ta } 6 \\
\text { holigan esir alındı. }\end{array}$ & $\begin{array}{l}\text { Protestolar yayıldı, } \\
\text { Ahvaz’da Condi Şapur Üniv. } \\
\text { eylemcilerce ele geçirildi. }\end{array}$ \\
\hline 4-5 Kasım 1978 & Katliam & $\begin{array}{l}\text { Ordu, Tahran Üniv. } \\
\text { öğrencilerinin üzerine ateş } \\
\text { açtı, çok sayıda kişi öldü. }\end{array}$ & $\begin{array}{l}\text { Ertesi gün Şah’’n heykeli } \\
\text { indirilip yüzlerce hükümet } \\
\text { binası ve banka ateşe verildi. }\end{array}$ \\
\hline 6 Kasım 1978 & $\begin{array}{l}\text { Sikıyönetim, } \\
\text { Katliam }\end{array}$ & $\begin{array}{l}\text { Arak'ta } 40 \text { gösterici } \\
\text { katledildi. }\end{array}$ & $\begin{array}{l}\text { Sıkıyönetime rağmen heykel } \\
\text { ve binalara saldırılar dinmedi }\end{array}$ \\
\hline 12 Kasım 1978 & Yürüyüş & Mazendaran'da protesto & $\begin{array}{l}\text { Muhalifler şehrin kontrolünü } \\
\text { ele geçirdi. }\end{array}$ \\
\hline
\end{tabular}

39 Ahavi, İran'da Din ve Siyaset, s.236. 


\begin{tabular}{|c|c|c|c|}
\hline 16 Kasım 1978 & Çatışma & $\begin{array}{l}\text { Öğrenciler, polis evlerine } \\
\text { saldırdı. Isfahan'da } 3 \text { er el } \\
\text { bombasılyla öldürüldü. }\end{array}$ & $\begin{array}{l}\text { Olaylar Zanjan'da büyük bir } \\
\text { yürüyüşe dönüştü, Şah’ın ve } \\
\text { kraliçenin heykelleri yıkıldı. }\end{array}$ \\
\hline 19 Kasım 1978 & Yürüyüş & $\begin{array}{l}\text { Nişabur'da iki gösterici } \\
\text { öldürüldü. }\end{array}$ & $\begin{array}{l}\text { Karşıllığında iki polis } \\
\text { öldürüldü. }\end{array}$ \\
\hline 21 Kasım 1978 & Miting & $\begin{array}{l}\text { Gonabad'da konuşmalar } \\
\text { yapıldı, Amol'da öğrenciler } \\
\text { silahlandı. }\end{array}$ & $\begin{array}{l}\text { Konuşmada rejimi savunan } \\
\text { bir askerin, Amol'da da } 3 \\
\text { polisin silahlarına el kondu. }\end{array}$ \\
\hline 22 Kasım 1978 & Yürüyüş & $\begin{array}{l}\text { Isfahan’da polis yürüyen } \\
\text { kalabalığa ateş açtı. }\end{array}$ & $\begin{array}{l}\text { Polis müdahalesi molotofla } \\
\text { karşılandı, esnaf tutuklandı. }\end{array}$ \\
\hline 22 Kasım 1978 & Çatışma & $\begin{array}{l}\text { Rafsanjan'da siyasi } \\
\text { mahkumların karşılanışı } \\
\text { iki göstericinin ölümü ile } \\
\text { sonuçlandı. }\end{array}$ & $\begin{array}{l}\text { Karşılığında İslamcı gerilla iki } \\
\text { polis şefini infaz etti. }\end{array}$ \\
\hline 24 Kasım 1978 & Çatışma & $\begin{array}{l}\text { Dezful'da } 7 \text { asker el } \\
\text { bombasıyla öldürüldü. }\end{array}$ & $\begin{array}{l}\text { Birkaç gün sonra } 10 \text { asker } \\
\text { daha öldürüldü. }\end{array}$ \\
\hline $\begin{array}{l}\text { Kasım sonu/ } \\
\text { Aralık başı } 1978\end{array}$ & Çatışma & $\begin{array}{l}\text { Ahvaz'da } 2 \text { polis ateş açıp } 6 \\
\text { yaşında bir kızı öldürdü. }\end{array}$ & $\begin{array}{l}\text { Ahvaz sakinleri ateş eden iki } \\
\text { polisi öldürdüler. }\end{array}$ \\
\hline 9 Aralık 1978 & Çatışma & $\begin{array}{l}\text { Ahvaz'da çok sayıda polis } \\
\text { öldürüldü, silahları alındı. }\end{array}$ & $\begin{array}{l}\text { Karşıllığında Amol'da } \\
\text { göstericiler katledildi. }\end{array}$ \\
\hline 9 Aralık 1978 & Çatışma & $\begin{array}{l}\text { Zanjan'da polis kadınlar } \\
\text { hamamına gaz bombası attı. }\end{array}$ & $\begin{array}{l}\text { Halk } 4 \text { güvenlik görevlisi ve } \\
20 \text { askeri öldürerek cevap } \\
\text { verdi. }\end{array}$ \\
\hline 11 Aralık 1978 & Yürüyüş & $\begin{array}{l}\text { Najaf Abad ve Isfahan'da } \\
\text { olaylar çıtı. }\end{array}$ & $\begin{array}{l}\text { Heykellere, karakol, banka ve } \\
\text { sinemalara saldırı oldu. }\end{array}$ \\
\hline 26 Aralık 1978 & Çatışma & $\begin{array}{l}\text { Tahran'da } 3 \text { güvenlik timi ve } \\
4 \text { askerî görevli öldürüldü. }\end{array}$ & $\begin{array}{l}\text { İddiaya göre, daha önce petrol } \\
\text { işçilerine ateş açmış ve bir } \\
\text { camiyi bombalamı̧̧lardı. }\end{array}$ \\
\hline $\begin{array}{l}26-27 \text { Aralık } \\
1978\end{array}$ & Çatışma & $\begin{array}{l}\text { İran Genelinde çatışmalar } \\
\text { devam etti. Nahavand'da } \\
\text { köylüler de protestoya } \\
\text { katıldılar. }\end{array}$ & $\begin{array}{l}1 \text { askerî görevli öldü, } 5 \text { asker } \\
\text { yaralandı; ertesi gün } 2 \text { asker } \\
\text { daha öldü. }\end{array}$ \\
\hline
\end{tabular}

Tablo 1'de görüldügü üzere, halkın içindeki muhtelif gruplar, devlet terörüne silah11-silahsız direnişle mukavemet gösteriyordu. Artık rejimle uzlaşmanın imkanı kalmamıştı. Muhalif grupların yeknesak bir örgütlenme olmadığını ancak birleşerek ortak bir söylemi hakim kıldıklarını söyleyebiliriz. Elimizde bu söylemin İslam'dan ayrı düşünülemeyeceğini gösteren yeterli veri var. Örneğin 1978’in sonunda Şiiler için kutsal olan Muharrem ayı ülke genelinde görülmemiş büyüklükte protestolara ve devlet terörü nedeniyle yeni ölümlere sahne oldu. Onları başka bir zaman değil de bu kutsal günlerde bir araya getiren, Muharrem ayının Şiiliğin tarihselliği içindeki merkezî önemiydi. 
Şia inanc1, Hz. Hüseyin ve beraberindekilerin Muharrem ayının 10. gününde şehit edilmesi üzerine inşa edilmiştir ve "icat edilmiş gelenekler" ${ }^{40}$ sayesinde yüzyıllardır yaşatılmış, siyasal anlamlar kazanmıştır. 2 Aralık 1978'de başlayan gösterilerde sokaklar "Allahu ekber” sesleriyle yankılanmıştır. Abrahamian, üç gün içinde 700 kişinin öldügünü, Gazvin'de 135 kişinin, Meşhed'de 200 öğrencinin tanklarla katledildiğini yazmaktadır. ${ }^{41}$ Charles Kurzman ise, 10-11 Aralık'ta ülke nüfusunun \%10'undan fazlasının yürüyüşlere katıldığını belirtmektedir. ${ }^{42} \mathrm{Bu}$, devletin ilga olduğunun ve Şah rejiminin sona erdiğinin herhalde en açık göstergesiydi.

Bu gösteriler sırasında gönderdiği bildirilerde Humeyni, hem İslam için hem de İran için savaşmayı öğütlemiştir. Bu gözü pek mesajlar tereddütsüz ölüme koşan insanları etkilemiştir. 1978'in sonuna gelindiğinde o, artık fikirlerinden görece bağımsız bir imgeye dönüşmüştür. Şiilerin ortak hafızasında o, Şah’a başkaldıran kahraman ve Yezid'e isyan eden din adamıdır. Artık o, 12 İmam’ı hatırlatan “İmam Humeyni” ismiyle anılacaktır. Bununla birlikte, İran'da devrimin aktif bir liderinden söz etmek mümkün değildir. Yalnızca Humeyni’nin sembolik liderliğinden söz edilebilir ki o da muhalif hareketlerin en yoğun olduğu 1964-1979 arasındaki on beş yıl boyunca sürgünde kaldığı için devrimci grupları bizzat örgütleme imkanı bulamamıştır. Humeyni’nin sürgünden yolladığ o, bu devrimin bedel ödeyeni, daha açık bir ifadeyle öznesi değildir. Humeyni’nin 1963 ’te gönderildiği sürgünden verdiği mesajlar, rejimin meşruiyet kanallarını aşan başka bir meşruiyet kaynağının oluşturulmasına katkı yapmıştı ve aslında söz konusu meşruiyet, İran topraklarında bir süreklilik taşıyan "İslamî yönetim” tasavvuruna dayanmaktadir.

Michel Foucault, İran'da tanıştığı Ayetullah Şeriatmedari`nin şöyle dediğini nakleder: «Mehdi>yi bekliyoruz ama iyi bir hükümetimiz olsun diye her gün savaşıyoruz.» ${ }^{43}$ «İyi hükümet» İslamî yönetim demektir. Michel Foucault İranlılara ne istediğini sorduğunda beş kişiden dördünün İslamî yönetim cevabını verdiğini söyler. Fakat İslamî Yönetim kavramı herkesin kafasında aynı değildir. Misagh Parsa'ya göre Humeyni’yi destekleyenler de onun İslamî Yönetim ile neyi kast ettiğini bilmemektedir. ${ }^{44}$ Foucault muhalif hareketlerin sistem içi bir çözüme razı edilemeyeceğini vurgular. Onu heyecanlandıran ise, bu isyanın, bildiğimiz Batı normlarında bir şey olmayışıdır. Yeni İran'ın nasıl kurulacağı, İslamî devrimin ne getireceği meçhuldür ama bu mücadeleye saygı duyulmalıdır. ${ }^{45}$

O, İranlıların bir arkaizm olan modernleşmeyi aştığını iddia etmiştir. İran’daki tüm toplumsal sınıflar rejimin temeli olan modernleşmeden rahatsızdır. Şah»ın suçu, mo-

40 Eric J. Hobsbawn ve Terence Ranger, Geleneğin İcadı, çev., Mehmet Murat Şahin, Ankara: Agora Kitaplığı, 2005, s.303.

41 Abrahamian, Iran Between Two Revolutions, s.521.

42 Charles Kurzman, The Unthinkable Revolution in Iran, Cambridge: Harvard University Press, 2009, s.121.

43 Janet Afary ve Kevin B. Anderson, Foucault ve İran Devrimi: Toplumsal Cinsiyet ve İslamcılı̆̆ın Ayartmaları, çev., Mehmet Doğan, İstanbul: Boğaziçi Üniversitesi Yayınları, 2015, s.256.

44 Misagh Parsa, "Ideology and Political Action in the Iranian Revolution", Comparative Studies of South Asia, Africa and the Middle East, 31/1 (2011), s.66.

45 Afary ve Anderson, Foucault ve İran Devrimi: Toplumsal Cinsiyet ve İslamcılı̆̆ın Ayartmaları, s.319. 
dernizmle uyumlu bir despotluk kurmuş olmasıdır. Şah, çağının gerisindedir; onun modernleşme projesi yıkılmaya mahkûmdur.

Misagh Parsa'ya göre devrimin yapısal temelinde, devlet merkezli modernleşme ve onun yıkıcı etkileri vardır. Choncheh Tazmini ise, rejimin tepeden inme modernizmine reaksiyon olarak İranlıların modern bir tepki verdiklerini vurgular ve devrim sürecini "aşağıdan modernleşme" olarak tarif eder. ${ }^{46}$

Gerçekten, 1970’ler İran’ında kitlelere yön veren fikirler modern fikirlerdi. Ali Mirsepassi’nin de vurguladığı gibi, 20. yüzyıl Müslüman entelektüelleri, 'Batı'yı, moderniteyi ve demokrasiyi ağırlıklı olarak aydınlanma karşıtı metinler üzerinden okudular. ${ }^{47}$ Dolayısıyla hem Avrupa'da yapılan teknik, endüstri, modernite vesaire hakkındaki tartışmalara yakın oldular, hem de bu metinlerin etkisiyle kendi eleştirel konumlarını aldılar. Mirsepassi’ye göre modernite, İranlı Müslümanların coğrafi, kültürel ve tarihsel deneyimine yabancı değildi, dolayısıyla onu yalnızca Avrupa Tarihi'ne ait bir anlatı ya da Avrupalı bir fenomen olarak okumak mümkün değildir. ${ }^{48}$ Eğer modern devleti, Peter Amman'ın dediği gibi "geniş bir alanda fiziksel güç, yönetim ve adaleti elinde bulunduran kurum" ${ }^{49}$ diye tanımlarsak, bu tekeli kırmaya yönelik devrimci hareketlerin modern devletin hakimiyet biçimlerine karşıt geliştiğini söyleyebiliriz. Ancak bu konum, devrimci hareketleri modernite tecrübesine içkin olmaktan al1koymaz. Dolayısıyla İran'daki İslamî Devrim olgusu da, tıpkı İslamcılık gibi modern bir tecrübedir, diyebiliriz.

\section{Sonuç}

Devrim kavramının hangi tartışmaları çağırdığını, hangi tartışmalardan yola çıkılarak hangi anlamları aldığını anlamaya çalıştık. Bu bağlamda, devrim kelimesinin akademik literatür dahilinde hep "değişim” olgusuyla birlikte anıldığını gördük. Hem İngilizce hem Fransızca hem de Arapçada devrim kavramının farklı etkilerle bugünkü siyasi anlamına evrildiği söylenebilir. Devrim kavramının Fransız Devrimi’nden sonra aldığı siyasi anlamlara paralel olarak Kur’an çevirilerindeki "inkılap" sözcüğünün anlaşılma biçimlerine değindik.

Girişteki teorik tartışmaların çerçevesinde İran'daki İslamî devrimi ani ve köklü değişim olarak tanımlamamız ve hem bir süreklilik hem de bir kopuş olarak tarif etmemiz yerinde olur. Sosyal bilimler literatürünün devrim kavramına yaptığı izahlar 1şığında İran Devrimi’nde, 1 . hem devletin kurumlarında ve kadrolarında alaşağ olma (Şah’ın ülkeyi terk etmesi, hükümetin istifa etmesi ve ordunun yenilgiyi kabul etmesi); 2. yalnız devletin iktidar mekanizmalarında değil toplumsal yaşayışta radikal bir değişim (1977-1979 döneminde esnaf ve işçi grevlerinin piyasayı alt üst etmesiyle alternatif ağların kurulmuş olması ve güvenliğin muhalif molla ve silahlı gruplar tarafından sağlanması); 3. bu değişimin doğal seyrinden çok daha hızlı ol-

46 Tazmini, Revolution and Reform in Russia and Iran, s.24.

47 Mirsepassi, Political Islam, Iran, and the Enlightenment: Philosophies of Hope and Despair, s.117.

48 Mirsepassi, Political Islam, Iran, and the Enlightenment: Philosophies of Hope and Despair, s 71.

49 Peter Amman, "Revolution: A Redefinition”, Political Science Quarterly LXXVII (1962) kaynağından aktaran

Lawrence Stone, “Theories of Revolution”, World Politics 18, 1966, s.173. 
ması (yani Şah rejiminin yasal sınırları içinde gerçekleşemeyecek yollarla); 4. bütün yasal ve meşru sınırları aşan ve alaşağı eden yeni bir meşruiyet kaynağı bulup doğurması (İranlı Müslümanlar nezdinde bir İslamî yönetim tahayyülü) söz konusudur.

İslamî yönetim tahayyülü, Şiiliğin tarihselliği içinde anlam kazanan, tekrar tekrar oluşturulan bir en iyi yönetim idealinden başka bir şey değildir. Kendiliğinden, Allah'ın dini olması sebebiyle en iyi olacağına inanılan İslamî yönetimin adaleti tesis edeceğine şu veya bu ölçüde iman edilmiş görünüyor. Ancak bu yönetimin, gökten inmeyeceği, çok çalışarak ve çabalayarak oluşturulacağı da biliniyordu. İranlılar, daha iyisini hak ettiklerine, (Müslümanlar ve/veya İranlılar olarak en iyisine layık olduklarına) tüm dünyaya örnek olacak adil bir yönetimi kuracaklarına inanmışlardı. Materyal koşullar dahilinde bir hakikat söylemi ve protesto geleneği inşa eden İranlılar, siyasetin düzenleyici gücüne karşı infial, direniş veya kabullenmeler yoluyla cevap verdiler. İşçinin, esnafın, öğrencinin, aydının ve mollanın Şah karşıtı mücadelesinin zamanla topyekün bir toplumsal harekete dönüşmesi bunun en açık göstergesiydi.

Görüldüğü gibi, İslamî Devrim’in etkin bir liderinden bahsetmek ya da devrimin belirli gruplar ya da toplumsal sınıflar tarafından gerçekleştirildiğini söylemek mümkün değildir. Sadece Humeyni’nin “önderliği” hakkında konuşulabilir: İslamî yönetim tahayyülü, Humeyni’nin sembolik rolü çerçevesinde ortak bir dile dönüştürüldü. Ne var ki o da muhalif hareketin en yoğun olduğu 1964-1979 yilları arasında 15 yıl boyunca sürgünde olduğu için devrimci grupları bizzat örgütleme fırsatı bulamamıştır. Adalet ve eşitlik uğrunda ölen çok sayıda insana kıyasla o, sürgüne gitmek dışında herhangi bir bedel ödememiştir. Daha açık bir ifadeyle, Humeyni, Şah rejimine açıkça meydan okuyabilen bir figür olması sebebiyle İslamî Devrim’in sembolü olmuştu fakat devrimin öznesi değildi. İyi bir yönetim idealiyle bir araya gelen kişilerin/grupların eylemliliğini geleceğe taşıyanlar da sadece $\mathrm{Hu}$ meyni ve muhalif ulema değil, aynı zamanda petrol işçileri, maden işçileri, kamu çalışanları, entelektüeller, her sınıftan tüccarlar, esnaf, beyaz yakalılar ve öğrencilerdi.

Bir kopuş olarak İran devrimi gittikçe ortaklaşan muhalif hareketlerin Humeyni tarafından nasıl üstlenilip eskisinden tamamen farklı olacak yeni bir yönetime nasıl ortam hazırlandığını göstermiştir. 1978'de yoğunlaşan eylemler karşısında hükümetin tek yapabildiği ordu ve güvenlik güçleriyle şiddet üretmekti. Ancak, "zor kullanımı" anlamındaki bu şiddet karşısında, muhalifler "ihlal olarak şiddet” yaratan grevlerle direndiler. Dolayısıyla İran devrimi özelinde İslamî Devrim de (diğer devrimler gibi) şiddet olgusundan bağımsız değildir ve tıpkı diğer devrimler gibi halkın özneliğine dayanır. Bununla birlikte, İslamî Devrim kavramı, söz konusu devrimin öznesi olan Müslümanlar için bir meşruiyeti imlediği sürece süreklilik taşır. İran’da devrim, kendi meşruiyetini İslamî yönetim isteğini dile getiren, çoğunluğu Müslüman olan halk nezdinde sağlamıştır. Bu meşruiyet, eski rejimden kopuşu ve yeni bir kurumsallaşmayı getirmiştir. Öte yandan bu çalışmadaki tartışmalar ışığında İslamî devrim, halkların özneliği kadar Allah’ın adaletinin er geç geleceği ve zulmü kendi haline bırakmadığı inancına dayanır. 


\section{Kaynakça}

Abrahamian, Ervand. Iran Between Two Revolutions. Princeton: Princeton University Press, 1982.

Afary, Janet ve Kevin B. Anderson. Foucault ve Iran Devrimi: Toplumsal Cinsiyet ve İslamcılı̆̆ın Ayartmaları. Çev., Mehmet Doğan. İstanbul: Boğaziçi Üniversitesi Yayınları, 2015.

Aktay, Yasin. “Sunuş”. Modern Türkiye’de Siyasî Düşünce: İslâmcılık. İstanbul: İletişim Yayınları, 2004.

Amman, Peter. "Revolution: A Redefinition”. Political Science Quarterly. LXXVII (1962): 36-53.

Arendt, Hannah. On Revolution. New York: Viking Press, 1963.

Bayat, Asef. Workers and Revolution in Iran: A Third World of Experience of Workers' Control. London: Zed Books Ltd., 1987.

Boroujerdi, Mehrzad. İran Entelektüelleri ve Batı. Çev., Fethi Gedikli. İstanbul: Yöneliş Yayınları, 2011.

Çelebi, Aykut. “Bir Parıltı... Sonra Gece”. Şiddetin Eleştirisi Üzerine. İstanbul: Metis Yayınları, 2010.

Dabashi, Hamid. Iran: A People Interrupted. New York: New Press, 2008.

Felsefe Ansiklopedisi. Ed., Ahmet Cevizci . 4. cilt. Ankara: Babil Yayınları, 2006.

Griewank, Karl. Der neuzetliche Revolutionsbegriff. Suhrkamp: Frankfurt-am-Main, 1973.

Guha, Ranajit. Dominance without hegemony: History and power in colonial India. Cambridge: Harvard University Press, 1997.

Hatto, Arthur. "Revolution: An Inquiry into the Usefulness of an Historical Term". Revolution: Critical Concepts in Political Science. Ed., Rosemary H. T. O’Kane. London: Routledge, 2000.

Hobsbawm, Eric. "Revolution". Revolutions in History. Ed., Roy Porter and Mikulas Teich. Cambridge: Cambridge University Press, 1986.

Hobsbawm, Eric J. ve Terence Ranger. Geleneğin İcadı. Çev., Mehmet Murat Şahin. Ankara: Agora Kitaplığı. 2005.

“Kur’an-1 Kerim Türkçe Meali”. Haz., Elmalılı Hamdi Yazır. Son güncelleme 25 Mart, 2018, http://www.kuran.gen.tr/?x=s_main\&y=s_middle\&kid=31\&sid=26.

“Kur’an Mesajı Meal ve Tefsir”. Haz., Ahmet Ertürk ve Cahit Koytak. Son güncelleme 25 Mart, 2018, http://www.kuran.gen.tr/?x=s_main\&kid=31\&sid=1\&y=s_ middle.

Kurzman, Charles. The Unthinkable Revolution in Iran. Cambridge: Harvard University Press, 2009.

Kramnick, Isaac. "Reflections on Revolution: Definition and Explanation in Recent Scholarship". History and Theory. 11 (1972): 26-63.

Mirsepassi, Ali. Political Islam, Iran, and the Enlightenment: Philosophies of Hope and Despair. Cambridge: Cambridge University Press, 2010. 
Muhammed, Hamide. İran İslam İnkılabı. Çev., M. Selman. Ankara: Kevser Yayınları, 1993.

Parsa, Misagh. Social Origins of the Iranian Revolution. Rutgers: Rutgers University Press, 1989.

Parsa, Misagh. "Ideology and Political Action in the Iranian Revolution". Comparative Studies of South Asia, Africa and the Middle East, 31/1 (2011): 53-68.

Rey, Alain. "Révolution”. Histoire d'un mot. Paris: Gallimard, 1989.

Schrecker, Paul. "Revolution as a Problem in the History of Philosophy". Revolution. Ed., Card J.Friedrich, Atherton: Atherton Press, 2009.

Shakibi, Zhand. Revolution and the Collapse of the Monarchy: Human Agency and the Making of Revolution in France, Russia and Iran. London: I.B.Tauris, 2007.

Skocpol, Theda. "Rentier State and Shia Islam in the Iranian Revolution". Theory and Society. 11/3 (1982): 265-283.

Sorel, Georges. Réflexions sur la Violence. Paris: Libraire des Sciences Politiques et Sociales, 1910.

Stone, Lawrence. “Theories of Revolution”. World Politics 18, 1966.

Tazmini, Choncheh. Revolution and Reform in Russia and Iran. I.B.Tauris, New York 2012.

“The Message of the Qur'an”. Haz., Muhammad Asad. Son güncelleme 25 Mart, 2018. http://www.kuran.gen.tr/?x=s_main\&y=s_middle\&kid=33\&sid=26.

Tilly, Charles. "Does Modernization Breed Revolution?”. Comparative Politics. 5 (1973): 425-447.

Yar-Shater, Ehsan. Iran Faces the Seventies. New York: Praeger Publishers, 1971.

Zagorin, Perez. "Prolegomena to the Comparative History of Revolution in Early Modern Europe". Comparative Studies in Society and History. XVIII (1976): 151174. 
İNSAN\&İNSAN, Y1l/Year 6, Say1/Issue 20, Bahar/Spring 2019, 307-323

DOI: https://doi.org/10.29224/insanveinsan.409392

\title{
What is Islamic Revolution?: The Case of Iran (1979)
}

\author{
Mehmet TAlha PaşaoĞlu
}

Abstract: Iranian Revolution (1979) is known within the literature of social sciences as the "Islamic Revolution". In this study, Islamic Revolution will be discussed in relation to the example of Iranian Revolution. First, we will look at the discussions regarding the question of "what is revolution" and we will focus on the issue of how the concept is used both within the literature of social sciences and within Islamic sources. After making a definition of Islamic Revolution with reference to these discussions, Iranian Revolution will be analyzed both as continuity and as rupture. Islamic Revolution in this study refers to the faith that justice, soon or late, will become a fact as a reflection of Allah's name, al-Adl. And from this perspective, Iranian Revolution, a unique example of the radical and rapid change in the 20th century, has left an indelible mark.

Keywords: Revolution, Iran, Islamic Revolution, Islam. 